\title{
P01-010 - Anti-TNF agents in intractable FMF: four cases
}

\author{
L Kaly ${ }^{*}$, D Rimar, G Slobodin, N Jiries, I Rosner, M Rozenbaum \\ From 7th Congress of International Society of Systemic Auto-Inflammatory Diseases (ISSAID) \\ Lausanne, Switerland. 22-26 May 2013
}

\section{Introduction}

Familial Mediterranean Fever (FMF) is an autoinflammatory disease characterized by recurrent attacks of fever and serositis. A relation between FMF and Ankylosing Spondylitis (AS) has been suggested in small cohort studies, although there is no consensus regarding the role of HLA B27. Colchicine, the mainstay treatment in FMF, does not improve the axial or peripheral symptoms due to spondylarthropathy. There are controversial data about the efficacy of Tumor Necrosis Factor Alpha (TNF $\alpha$ ) blockade in FMF patients [1].

\section{Case Report}

We report our experience in 4 patients with intractable FMF treated with oral colchicine and supplemental weekly IV colchicine [2], that were treated with TNF $\alpha$ blockade for symptomatic axial spondylarthropathy.

One 26 years old man with MEFV mutations V726A and E148Q, negative for HLAB27, with concomitant ulcerative colitis was treated with infliximab and then with adalimumab; and 3 women (42, 48 and 55 years old), two of them treated with Infliximab and one treated with adalimumab. Two of the women were homozygous for the M694V mutation. All developed severe to moderate adverse events: exacerbation of FMF in 2 of them, myositis and ulcerative colitis exacerbation in the male patient, and staphylococcus aureus sepsis in another patient. Three of them had to stop the TNF $\alpha$ blockade treatment. One patient developed psoriatic rash, with no need to stop the treatment.

\section{Discussion}

In our limited experience, TNF $\alpha$ blockade in patients with both intractable FMF and AS is not very effective and may be associated with severe adverse events. Little is

Rheumatology, Bnai Zion medical Center-Haifa Israel, Haifa, Israel known about the possible interaction between intravenous colchicine and anti-TNF treatment.

\section{Disclosure of interest}

None declared.

Published: 8 November 2013

\section{References}

1. Bilgen SA, Kilic L, Akdogan A, Kiraz S, Kalyoncu U, Karadag O, Ertenli I, Dogan I, Calguneri M: Effects of anti-tumor necrosis factors agents for familial Mediterranean fever patients with chronic arthritis and/ or sacroiliitis who were resistant to colchicine treatment. J clin Rheumatol 2011, 7:358-62.

2. Rozenbaum M, Boulman N, Feld J, Avshovich N, Petrovich S, Elias M, Slobodin G, Rosner I: Intravenous colchicine treatment for six months: adjunctive therapy in Familial Mediterranean fever (FMF) unresponsive to oral colchicine. Clin Exp Rheumatol 2009, 27(2 suppl 53):S 105.

doi:10.1186/1546-0096-11-S1-A14

Cite this article as: Kaly et al:: P01-010 - Anti-TNF agents in intractable FMF: four cases. Pediatric Rheumatology 2013 11(Suppl 1):A14.

Submit your next manuscript to BioMed Central and take full advantage of:

- Convenient online submission

- Thorough peer review

- No space constraints or color figure charges

- Immediate publication on acceptance

- Inclusion in PubMed, CAS, Scopus and Google Scholar

- Research which is freely available for redistribution (c) 2013 Kaly et al; licensee BioMed Central Ltd. This is an Open Access article distributed under the terms of the Creative Commons Attribution License (http://creativecommons.org/licenses/by/2.0), which permits unrestricted use, distribution, and reproduction in any medium, provided the original work is properly cited. 